\title{
Агробиологические, физиолого-биохимические и технологические особенности винограда сорта Рислинг рейнский в условиях изменяющегося климата юга России
}

Валерий Семенович Петров, д-р с.-х. наук, доцент, зав. научным центром "Виноградарство", toksikolog@mail.ru;

Галина Юрьевна Алейникова, канд. с.-х. наук;

Татьяна Павловна Павлюкова, канд. с.-х. наук;

Наталия Ивановна Ненько, д-р биол. наук;

Мария Александровна Сундырева, канд. биол. наук

Федеральное государственное бюджетное научное учреждение «Северо-Кавказский федеральный научный центр садоводства,

виноградарства, виноделия», 350901, Краснодарский край, г. Краснодар, ул. им. 40-летия Победы, д. 39

Аномальное проявление абиотических стрессоров умеренно континентального климата юга России сопровождается низкой конкурентоспособностью продукции виноградарства на потребительском рынке. В этих условиях актуальным является создание устойчивых ампелоценозов путем вовлечения сортов адаптивных к аномальным природным явлениям. Цель исследований установление агробиологических и физиолого-биохимических особенностей винограда сорта Рислинг рейнский для создания адаптивной сорториентированной технологии его устойчивого возделывания в стрессовых экологических условиях. В Черноморской зоне виноградарства (г. Анапа), распускание почек отмечалось 22 апреля при температуре воздуха $12,6^{\circ} \mathrm{C}$. Наиболее активный рост побегов отмечали в первой половине июня, 2,61 cм/сут Наибольшая скорость роста побегов наблюдалась при температуре $23^{\circ} \mathrm{C}$. Максимальная скорость роста была в зоне 4-9 междоузлий. Наибольшая длина побегов, 155 см, зафиксирована на участке с шириной междурядий $3 \mathrm{~m}$. Самые крупные листья, до $140 \mathrm{~cm}^{2}$, были в зоне наиболее активного роста побегов, на 4-6 узлах. Ростовые процессы листьев и плодоношение винограда находилось в тесной зависимости от плотности и схемы размещения кустов в насаждениях. В активной зоне побегов формировались наиболее крупные грозди. Наибольшая урожайность винограда была в среднеплотных насаждениях при размещении кустов по схеме 3,0 × 1,0 и 3,0 x 1,5 м - 12 т/ га. Дифференцированный отклик сорта на природные и антропогенные факторы согласуется с результатами физиолого-биохимических показателей фотосинтеза, коэффициента эффективности первичных процессов фотосинтеза, соотношения хлорофиллы/каратиноиды и содержания крахмала в листьях винограда. При повышенной инсоляции и остром дефиците атмосферных осадков, отмечалась общая тенденция снижения содержания хлорофиллов в листьях винограда. Максимальные значения этого показателя наблюдались в первой половине июня. В динамике во всех вариантах опыта наблюдалось увеличение крахмала в листьях винограда до середины июля. В дальнейшем количество крахмала постепенно снижалось. Применение сорт-ориентированной технологии со средней плотностью размещения кустов 2222 шт./га по схеме 3,0 x 1,5 м, обрезка побегов на 10 глазков, нагрузка побегами 23 шт./куст и гроздями 53 шт./куст обеспечивали наибольший уровень реализации фотосинтетического и продукционного потенциалов винограда. Урожайность в таких насаждениях была наибольшей и составляла в среднем 12 т/га.

Ключевые слова: виноград; Рислинг рейнский; абиотические стрессоры; агробиологические, физиологобиохимические, технологические особенности.
O R I G I N A L A R T I C L I C L E

Agrobiological, physiological, biochemical and technological peculiarities of 'Riesling of the Rhine' grapevine in the conditions of the climate change in the South of Russia

Valeriy Semionovich Petrov, Galina Yurievna Aleynikova, Tatiana Pavlovna Pavliukova, Nataliya Ivanovna Nenko, Mariya Alexandrovna Sundyreva

Federal State Budget Scientific Institution North Caucasian Federal Scientific Center of Horticulture, Viticulture, Winemaking, 350901, 39 40 Let Pobedy str., Krasnodar, Russian Federation

The abnormal manifestation of abiotic stressors of the moderately continental climate of the South of Russia is accompanied by low competitiveness of the viticultural products on the consumer market. In this context, establishment of sustainable ampelocenoses through the involvement of cultivars adaptive to abnormal natural phenomena is of interest at this time. The aim of the study was to establish agrobiological, physiological and biochemical peculiarities of 'Riesling of the Rhine' grapevine in order to create an adaptive variety oriented technology for its sustainable cultivation under stressful environmental conditions. The bud break in the Black sea viticultural zone (Anapa) was observed on April 22 with air temperature at $12.6^{\circ} \mathrm{C}$. The most active shoot growth was noted in the first half of June, $2.61 \mathrm{~cm} /$ day. The most intensive shoot growth was observed at a temperature of $23^{\circ} \mathrm{C}$. The maximum growth rate was in the zone of $4-9$ internodes. The greatest shoot length, $155 \mathrm{~cm}$, was observed at the plot with the row width of $3 \mathrm{~m}$. The largest leaves, up to $140 \mathrm{~cm}^{2}$, were observed in the area of most active shoot growth between the 4 - 6 nodes. The leaf growth processes and grapevine fertility depended closely on vine spacing and bush placement scheme. The largest bunches developed in the active shoot zone. The highest yield was obtained in the mediumdensity vineyards with the bush planting scheme of 3.0x1.0 and 3.0x1.5 $\mathrm{m}$, where the harvest made $12 \mathrm{t} / \mathrm{ha}$. The differentiated response of a cultivar to natural and anthropogenic factors was consistent with the results of the physiological and biochemical parameters of photosynthesis, the efficiency coefficient of the photosynthesis primary processes, the ratio between chlorophylls and carotenoids and starch content in the leaves of grapes. High insolation combined with acute deficit of atmospheric precipitation resulted in the general reduction of the chlorophyll content in the leaves of grapevines. These indicator maximum values were observed in the first half of June. During all the trial variants there was an increase in the starch content in the leaves of grapevines that lasted until mid-July. Subsequently, the starch content gradually decreased. Application of variety-oriented technol-

\section{Как цитировать эту статью:}

Петров В.С., Алейникова Г.Ю., Павлюкова Т.П., Ненько Н.И., Сундырева М.А. Агробиологические, физиолого-биохимические и технологические особенности винограда сорта Рислинг рейнский в условиях изменяющегося климата юга России // «Магарач». Виноградарство и виноделие, 2019; 21(3); C. 204-210. DOI 10.35547/IM.2019.21.3.004

\section{How to cite this article:}

Petrov V.S., Aleynikova G.Yu., Pavliukova T.P., Nenko N.I., Sundyreva M.A. Agrobiological, physiological, biochemical and technological peculiarities of 'Riesling of the Rhine' grapevine in the conditions of the climate change in the South of Russia. Magarach. Vinogradarstvo I Vinodelie = Magarach. Viticulture and Winemaking, 2019; 21(3):204-210. DOI 10.35547/IM.2019.21.3.004 (in Russian)

удК $634.8: 631.543$

Поступила 08.02.2019

Принята к публикации 20.08.2019

(C) Авторы, 2019 
ogy with an average vine spacing $2222 \mathrm{pcs}$./ha, planting pattern $3.0 \times 1.5$ $\mathrm{m}$, shoot pruning at 10 eyes, shoot load of 23 pcs./bush and clusters 53 $\mathrm{pcs}$./bush ensured the highest release of grapevine photosynthetic and production potential. Such vineyards produced the highest yields, which on average made $12 \mathrm{t} / \mathrm{ha}$.

Key words: Grapes; 'Riesling of the Rhine'; abiotic stressors; agrobiological, physiological and biochemical, technological peculiarities.

$\mathrm{P}$ ислинг рейнский явАяется широко известным и популярным сортом винограда из долины Рейна, возделываемым во многих винодельческих регионах. В Россию Рислинг был завезен не позднее начала XIX века, а на Кавказском побережье Черного моря его первые посадки были заложены в «АбрауАюрсо» в 1974 г. Ао сих пор интерес к сорту велик, так как из него получают высококачественные столовые, игристые вина и вина типа ice-wine [1-6]. Отечественные и зарубежные ученые продолжают изучение сорта Рислинг: его реакции на абиотические стрессоры [7-11], агротехнические приемы [12-14]. Изучают фенологию [15] и физиологию в условиях происходящих кмиматических изменений [16-20].

ОАной из наиболее острых проблем виноградарства является низкая устойчивость ампелоценозов к абиотическим стрессорам. В нестабимьных погодных условиях мокального изменения кмимата негативное воздействие стрессоров на винограА усиливается $[8,9,13,18]$. Следствием нарастающей частоты низкотемпературных стрессоров в период зимовки винограда, а также острого Аефицита атмосферных осадков на фоне аномамьно высоких температур воздуха в период вегетации насажАений явмяется повреждение культивируемых растений, впцоть Ао полной их гибели $[18,21]$. В этих условиях отмечается низкий уровень реализации потенциала хозяйственной продуктивности используемых сортов винограда. В Краснодарском крае этот показатель составляет в среднем $60 \%$. В Аругих регионах Северного Кавказа он еще ниже $[17,22]$. Нормативный срок эксплуатации насаждений винограда в России предельно низкий и составляет 25 мет, в европейских странах - Ао 60 мет, при биологически возможной продолжительности жизни растений 300 Ает [23]. Ростовые и продукционные процессы виноградной мозы находятся в тесной зависимости от генетически обусловленной реакции сорта на антропогенные и абиотические факторы среды обитания [24-28]. Более полная реализации биологического потенциала растений винограда в условиях аномального проявления абиотических стрессоров сопровожАается усложнением технологии воздемывания насаждений. В этих условиях актуальным является создание устойчивых ампемоценозов на основе вовлечения в сельскохозяйственное использование сортов адаптивных к абиотическим стрессорам умеренно континентального климата юга России. Знание биологии растений и их реакции на условия среды обитания позволяет оптимизировать технологию возделывания насаждений. У каждого сорта Аолжна быть своя технология возделывания, соответствующая его биологии и ресурсному потенциалу агротерритории.

Цемь наших исследований заключается в установмении агробиологических и физиолого-биохимических особенностей винограда сорта Рислинг рейнский амя разработки адаптивной сорториентированной технологии его устойчивого возделывания в нестабильных погодных условиях изменяющегося климата юга России.

Методика. Работа выполнена с использованием помевых и мабораторно-аналитических методов исследований [29]. Объектом исследований служили опытные насаждения винограда сорта Рислинг рейнский (г.Анапа). Насаждения привитыми саженцами по полной Авухфакторной схеме полевого опыта, 2010 г. посадки. Фактор 1 - ширина междурядий 3,5; 3,0 и 2,5 м, фактор 2 - межкустное расстояние в рядах насаждений 2,0; 1,5 и 1,0 м. Всего 9 вариантов опыта в трехкратной повторности.

Содержание пигментов (хморофимл А + B, каротиноиды), угмеводы (крахмал) опредемяли спектральным методом на приборе UNICO 2800 («United Products \& Instruments@, США). Аля статистического анализа использовали программу Statistika-99.

\section{Результаты и обсуждение}

Исследования фенологии сорта Рислинг и других сортов винограда проводими Pearce и Coombe (2004) на юге Австралии, Schultz в Германии (1992) [30, 31]. За рубежом на винограде вида Vitis labrusca проводими исследования схемы посадки кустов [32], а также отрабатывалась модель роста и развития виноградной цозы (на примере сорта Шардоне) [33].

Нашими исследованиями установмено, что в условиях юга России аля винограда сорта Рислинг рейнский начало распускания почек и последующий рост побегов отмечается в среднем 22 апреля, при повышении температуры возауха до $12,6^{\circ} \mathrm{C}$. Размах варьирования признака "среднесуточная температура воздуха", при котором наблюдалось начало ростовых процессов, варьировал от 9,9 a $14,6^{\circ} \mathrm{C}$.

Сразу после распускания почек отмечалось нарастание скорости роста побегов. Наиболее активный рост был в первой половине июня, сразу после цветения винограда. В этот период скорость была наибольшей и составцяла в среднем по опыту 2,61 см/сут. В посмедующем скорость нарастания побегов постепенно уменьшалась.

Скорость роста побегов винограда находилась в прямой зависимости от температуры воздуха, что подтвержАается исследованиями Hans R.Schultz [31] на других сортах винограда. Наибольшая скорость роста побегов винограда сорта Рислинг рейнский наблюдалась при температуре воздуха $23^{\circ} \mathrm{C}$. Корреляционная зависимость скорости роста от температуры составляла $\mathrm{r}=0,4$. Такая температура воздуха в Черноморской агроэкологической зоне виноградарства отмечается обычно в июне-июле и согласуется с наибольшей скоростью роста побегов винограда сорта Рислинг рейнский.

Реакция ростовых процессов на разную плотность и схему размещения кустов в насаждениях была неоднозначной. В начале вегетации, с 22 апреля до 20 мая, наи- 
Agrobiological, physiological, biochemical and

technological peculiarities of 'Riesling of the Rhine' grapevine ...

большая скорость роста побегов наблюдацась в разреженных насажАениях, с межАурядьями шириной 3,5 м. В послеАующем, с 20 мая по 15 июня, наибольшая ростовая активность быма в уплотненных насаждениях с шириной межАурядий 2,5 м. В конце наблюдений, в июле, наибольшая скорость была зафиксирована в насаждениях с шириной межАурядий 3,0 м. Наибольшая Алина побегов за время исследований была на участках винограда с шириной межАурядий 3 м и составляла 155 см (табл. 1).

Систематический учет Амины межАоузмий на побегах через семидневные интервацы кажАого отАельного поряАКового образования (межАоузиия) позволим установить биомогическую специфику сорта Рислинг рейнский. Исследованиями установлено, что межАоузмия по Алине побегов у изучаемого сорта растут с разной скоростью. У первого межАоузиия скорость роста самая низкая. Усименный рост начинается со второго межАоузАия. По мере удацения межАоузАий от основания побега скорость прироста их Алины увемичивается. Максимальная величина прироста наблюдалась в зоне 4-9 междоузмий. Скорость роста послеАующих межАоузАий Устойчиво снижалась. Бомее ускоренными темпами нарастание 2-9 междоузиий отмечалось на кустах винограда с разреженной посадкой по схеме 3,5 х 2,0 м по сравнению с уплотненными насаждениями - 2,5 х 1,0 м. В зоне 9-17 межАоузмий скорость роста на побегах устойчиво снижакась как в разреженных, так и в уплотненных насаждениях. Причем более интенсивно скорость роста уменьшалась в разреженных насаждениях. Следует отметить провац скорости прироста побегов в зоне седьмого межАоузАия, межАу Авумя пиками 6 и 8 межАоузмий.

Поскоцьку максимацьно растущая зона у винограда сорта Рислинг рейнский ограничивается 5-9 межАоузииями, он нуждается в обрезке побегов на 10 глазков с тем, чтобы стимулировать формирование наиболее проАуктивной зоны.

Установлено, что Аифференцированная скорость роста междоузиий сорта Рислинг

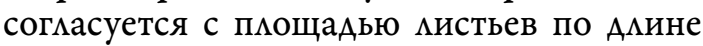
побега, что не противоречит исследованиям Antonio F. Nogueira Jünior [32] на Аругих сортах. Биометрические показатели $\Lambda$ истьев, как и скорость нарастания Алины межАоузиий, меняются по Алине побега. Самые маменькие $и$ итья формировамись у основания побегов. По мере уАацения от основания побегов размер мистьев увемичивался. Самые крупные мистовые пластинки, до $140 \mathrm{~cm}^{2}$, быми в зоне наиболее активного роста побегов, на 4-6 узмах в разреженных насажАениях со схемой посаАКи кустов $3,5 \mathrm{x}$ 2,0 м. Корремяционная взаимозависимость
Petrov V.S., Aleynikova G.Yu.,

Pavliukova T.P., Nenko N.I., Sundyreva M.A.

VITICULTURE

Таблица 1. Влияние плотности размещения и схемы посадки кустов на скорость роста побегов винограда сорта Рислинг рейнский, г. Анапа, 2015-2017 гг.

Table 1. The impact of vine density and bush planting scheme on shoot growth rate of 'Riesling of the Rhine' grapevine, Anapa, 2015-2017

\begin{tabular}{|c|c|c|c|c|c|c|}
\hline Схема & Пцотность & \multicolumn{5}{|c|}{ Скорость роста побегов в Аинамике, см/сут. } \\
\hline посаАКи & размещения & 22 апремя- & 20 мая- & 1 июня- & 15 июня- & 2 июмя- \\
\hline кустов, м & кустов, шт./Г & 20 мая & 2 июня & 15 июня & 2 июмя & 17 июця \\
\hline $3,5 \times 2,0$ & 1428 & 1,35 & 1,49 & 2,09 & 2,43 & 1,53 \\
\hline $3,5 \times 1,5$ & 1905 & 1,38 & 1,1 & 1,8 & 2,27 & 1,63 \\
\hline $3,5 \times 1,0$ & 2857 & 1,53 & 0,97 & 2,88 & 2,21 & 0,6 \\
\hline Среанее & 2063 & 1,42 & 1,19 & 2,26 & 2,3 & 1,25 \\
\hline $3,0 \times 2,0$ & 1667 & 1,5 & 1,23 & 2,57 & 2,04 & 2,07 \\
\hline $3,0 \times 1,5$ & 2222 & 1,24 & 1,88 & 2,61 & 2,19 & 2,2 \\
\hline $3,0 \times 1,0$ & 3333 & 1,31 & 1,57 & 2,49 & 2,07 & 1,41 \\
\hline Среанее & 2407 & 1,35 & 1,56 & 2,56 & 2,1 & 1,89 \\
\hline $2,5 \times 2,0$ & 2000 & 1,21 & 1,41 & 3,19 & 2,05 & 0,74 \\
\hline $2,5 \times 1,5$ & 2667 & 1,08 & 1,69 & 2,83 & 1,54 & 1,35 \\
\hline $2,5 \times 1,0$ & 4000 & 1,13 & 1,75 & 3,02 & 2,08 & 0,77 \\
\hline СреАнее & 2889 & 1,14 & 1,62 & 3,01 & 1,89 & 0,95 \\
\hline Cреднеe I & опыту & 1,3 & 1,46 & 2,61 & 2,09 & 1,36 \\
\hline
\end{tabular}

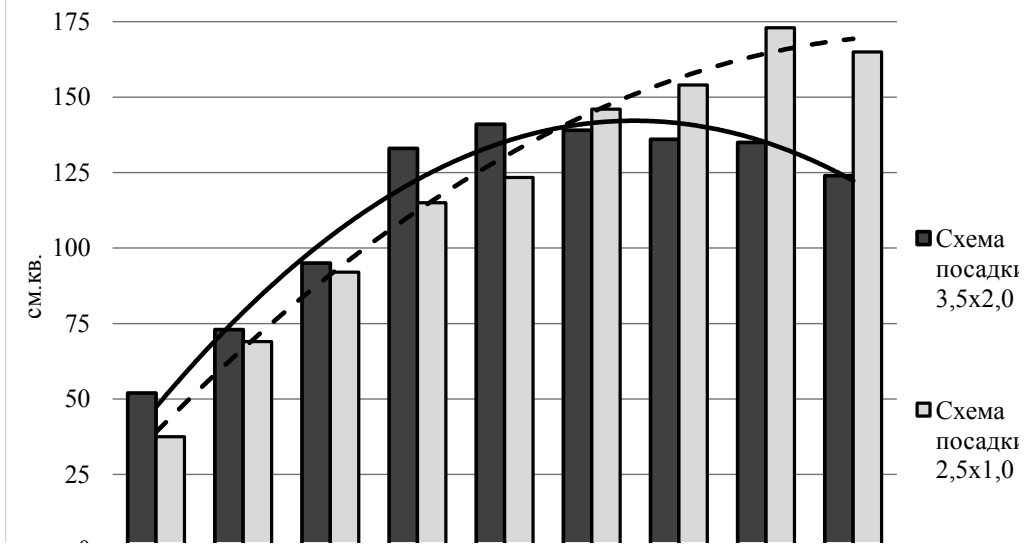

Рис. 1. Изменение площади листовой пластинки по длине побега, сорт Рислинг рейнский, г. Анапа, 2014 г.

Fig. 1. Leaf blade area change along the shoot length, 'Riesling of the Rhine' cultivar, Anapa, 2014

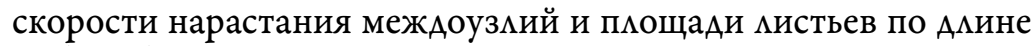
побега быма тесной и составцяма в разреженных насаждениях 0,73, в уплотненных - 0,77 (рис. 1).

Исследования показывают, что ростовые процессы мистьев и пцодоношение винограда сорта Рислинг рейнский находятся в тесной зависимости от схемы размещения кустов в насаждениях. Более активный рост, наибольшая площадь мистовых пластинок и облиственность побегов наблюдацись в среАнеплотных насажАениях с трехметровыми междурядьями. ПиощаАь Аистьев и облиственность побегов при такой ширине межАурядий была в среАнем 152 $\mathrm{cm}^{2}$ и $3201 \mathrm{~cm}^{2} /$ побег соответственно (табл. 2).

Наблюдения показаци, что в активной зоне побегов формируются наиболее крупные грозди. На плодоносящих побегах в зоне 2-4 глазков масса грозди составцяма в среднем по опыту 128-116 г. Причем в разреженных и среднеплотных насаждениях при посаАке кустов по схеме 3,5 х 2,0 и 3,0 x 1,0 м наиболее крупные грозди были ближе к основанию побегов, в зоне второго глазка. В упцотненных насажАениях при посаАке кустов по схеме 2,5 х 2,0 - 2,5 х 1,0 м формирование наиболее крупных гроздей сместияось в зону третьего и четвертого глазков. Скмонность растений к образованию побегов с высоким коэффициентом плодоносности (отношение общего коАичества гроздей к количеству плодоносных побегов на кусте) обе- 
Таблица 2. Влияние плотности и схемы посадки кустов винограда на облиственность побегов сорта Рислинг рейнский, г. Анапа

Table 2. The effect of vine density and bush planting system on leaf formation on the shoots of 'Riesling of the Rhine' cultivar, Anapa

\begin{tabular}{|c|c|c|c|c|c|c|c|c|}
\hline \multirow{2}{*}{$\begin{array}{l}\text { Схема посадки } \\
\text { кустов, м }\end{array}$} & \multicolumn{4}{|c|}{ 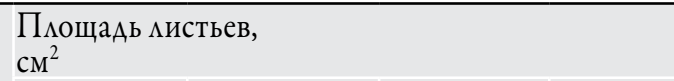 } & \multicolumn{4}{|c|}{$\begin{array}{l}\text { Обциственность побегов, } \\
\mathrm{cm}^{2} / \text { побег }\end{array}$} \\
\hline & 2015 & 2016 & 2017 & Среднее & 2015 & 2016 & 2017 & Среднеє \\
\hline $3,5 \times 2,0$ & 184 & 126 & 107 & 139 & 3931 & 2145 & 2769 & 2948 \\
\hline $3,5 \times 1,5$ & 204 & 132 & 93 & 143 & 3787 & 2037 & 2234 & 2686 \\
\hline $3,5 \times 1,0$ & 169 & 140 & 97 & 135 & 3580 & 3044 & 2611 & 3079 \\
\hline Среднее & 186 & 133 & 99 & 139 & 3766 & 2409 & 2538 & 2904 \\
\hline $3,0 \times 2,0$ & 197 & 141 & 103 & 147 & 3276 & 2064 & 2683 & 2675 \\
\hline $3,0 \times 1,5$ & 215 & 146 & 140 & 167 & 5352 & 2256 & 3352 & 3653 \\
\hline $3,0 \times 1,0$ & 175 & 152 & 97 & 141 & 3560 & 3360 & 2901 & 3274 \\
\hline Среднее & 196 & 146 & 113 & 152 & 4063 & 2560 & 2979 & 3201 \\
\hline $2,5 \times 2,0$ & 183 & 133 & 102 & 139 & 3701 & 2654 & 2341 & 2899 \\
\hline $2,5 \times 1,5$ & 181 & 128 & 123 & 144 & 2675 & 2274 & 3456 & 2802 \\
\hline $2,5 \times 1,0$ & 179 & 139 & 121 & 146 & 3928 & 2749 & 2892 & 3189 \\
\hline Среднее & 181 & 133 & 115 & 143 & 3435 & 2559 & 2897 & 2963 \\
\hline
\end{tabular}

Таблица 3. Влияние площади питания кустов на урожайность винограда Рислинг рейнский, г. Анапа, среднее за 2015-2017 гг.

Table 3. The root bed impact on fertility of 'Riesling of the Rhine' cultivar, Anapa, means for 2015-2017

\begin{tabular}{|c|c|c|c|c|c|c|c|c|c|}
\hline \multirow{2}{*}{$\begin{array}{l}\text { Схема } \\
\text { посаАки } \\
\text { кустов, м }\end{array}$} & \multirow{2}{*}{$\begin{array}{l}\text { Комичество } \\
\text { побегов, } \\
\text { шт./ куст }\end{array}$} & \multirow{2}{*}{$\begin{array}{l}\text { Количество } \\
\text { гроздей, } \\
\text { шт./ куст }\end{array}$} & \multirow{2}{*}{$\begin{array}{l}\text { Масса } \\
\text { грозАи, г }\end{array}$} & \multirow{2}{*}{$\begin{array}{l}\text { Продуктивность } \\
\text { побега, г }\end{array}$} & \multicolumn{5}{|c|}{ Урожайность, т/ га } \\
\hline & & & & & 2015 г. & 2016 г. & 2017 г. & 2018 г. & среднее \\
\hline $3,5 \times 2,0$ & 33 & 61 & 95 & 175 & 8,37 & 9,99 & 6,27 & 3,24 & 6,97 \\
\hline $3,5 \times 1,5$ & 26 & 48 & 96 & 169 & 10,08 & 9,50 & 7,60 & 4,51 & 7,92 \\
\hline $3,5 \times 1,0$ & 18 & 35 & 108 & 190 & 11,51 & 10,26 & 7,73 & 8,08 & 9,40 \\
\hline $3,0 \times 2,0$ & 30 & 57 & 100 & 192 & 9,33 & 11,42 & 8,50 & 11,92 & 10,29 \\
\hline $3,0 \times 1,5$ & 23 & 53 & 103 & 228 & 12,18 & 12,53 & 10,27 & 12,90 & 11,97 \\
\hline $3,0 \times 1,0$ & 15 & 35 & 101 & 228 & 8,66 & 16,03 & 10,47 & 15,42 & 12,64 \\
\hline $2,5 \times 2,0$ & 25 & 54 & 93 & 196 & 8,76 & 12,20 & 8,34 & 6,4 & 8,92 \\
\hline $2,5 \times 1,5$ & 20 & 35 & 105 & 160 & 11,73 & 9,28 & 7,76 & 9,3 & 9,52 \\
\hline $2,5 \times 1,0$ & 14 & 28 & 93 & 187 & 10,40 & 10,80 & 8,65 & 6,5 & 9,09 \\
\hline $\mathrm{HCP}_{05}$ & & & & & 0,88 & 1,11 & $\mathbf{0 , 8 0}$ & 1,0 & \\
\hline
\end{tabular}

спечивацо высокую урожайность винограда.

Наиболее урожайными были среднеплотные насаждения винограда с междурядьями шириной 3 м, при размещении кустов по схеме 3,0 х 1,0 и 3,0 х 1,5 м. Эти варианты отличались наибольшей продуктивностью побега и урожайностью с еАиницы площади насаждений (табл.3). Аифференцированный откиик винограда сорта Рислинг рейнский на природные и агротехнические факторы согласуется с результатами физиолого-биохимических показателей фотосинтеза, коэффициента эффективности первичных процессов фотосинтеза, соотношения хлорофимлы/каратиноиды и содержания крахмала в мистьях винограда.

Интенсивность фотосинтеза еАиницы поверхности $\Lambda$ иста возрастает с увеличением в нем хлорофимла. В среАнем за 4 года наблюдений (2014-2017 гг.) при повышенной инсоцяции и остром дефиците атмосферных осадков, особенно во второй половине вегетации (июнь-август) отмечалась общая тенденция снижения содержания хмо-

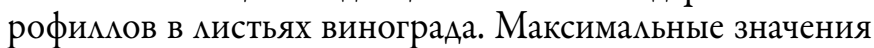
этого показатемя набцюдацись в первой половине июня, минимальные - в третьей декаде августа-сентябре, когда происходит активное сахаронакопиение в ягодах вино- града. Искмючение составмяет вариант насаждений со средней плотностью размещения кустов в насаждениях по схеме 3,0 х 1,5 м. ЗАесь наибольшее содержание хлоро-

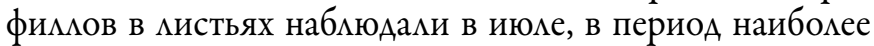
активного роста ягоА. В последующем, в августе, как и в Аругих насаждениях, отмечалось снижение содержания хлорофилмов. В этот период наибольшая стабильность пигментного аппарата была свойственна растениям, выращиваемым на большей площади питания, 3,5 х 2,0 м (рис. 2).

Коэффициент эффективности первичных процессов фотосинтеза (ЭППФ) опредемяли по соотношению пигментов светособирающего комплекса и пигментов фотосистем I и II [28-29]. В Аинамике с мая по август наблюдали снижение ЭППФ в вариантах с уплотнённым $(2,5 \times 1,0$ м $)$ и среднеплотным (3,0 x 1,5 м) размещением кустов винограда в насаждениях. При разреженном размещении кустов (3,5 х 2,0 м) этот показатемь бым наибомее стабимьным. Самое высокое значение ЭППФ бымо при среАнеплотном размещении кустов в насаждениях винограда во все сроки изучения, с мая по август вкцючительно.

Пигменты ксантофимового цикма накапливаются в 
Содержание крахмала в листьях винограда

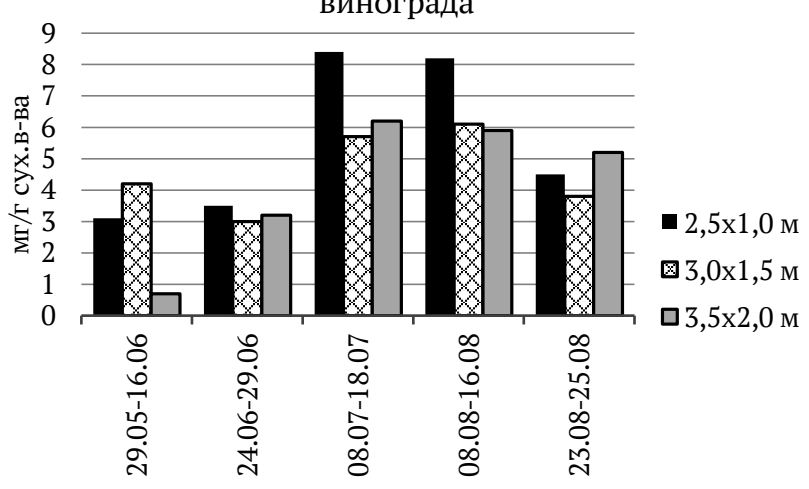

Содержание хлорофиллов в листьях винограда

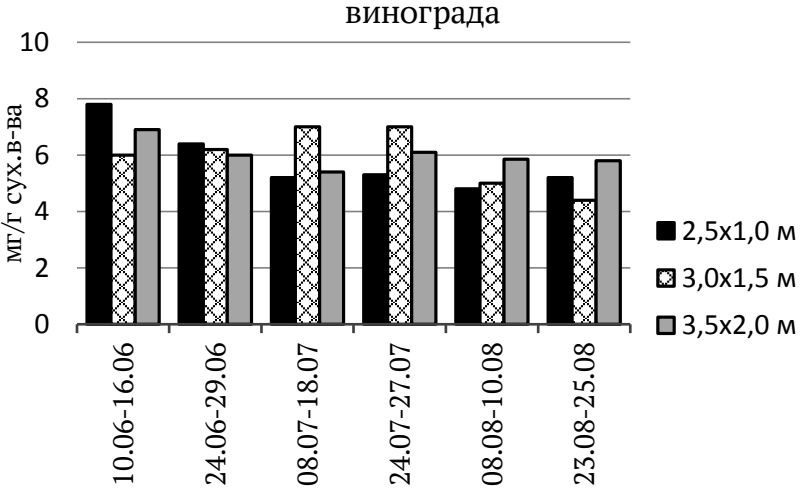

Соотношение хлорофиллы/каратиноиды

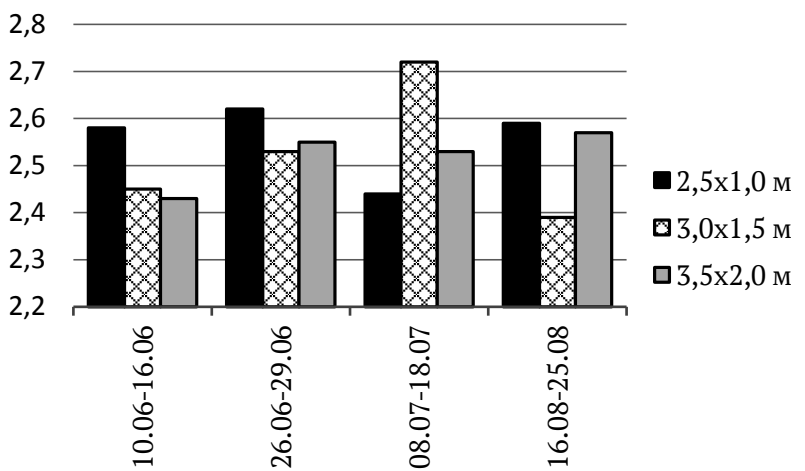

Коэффициент эффективности первичных процессов фотосинтеза

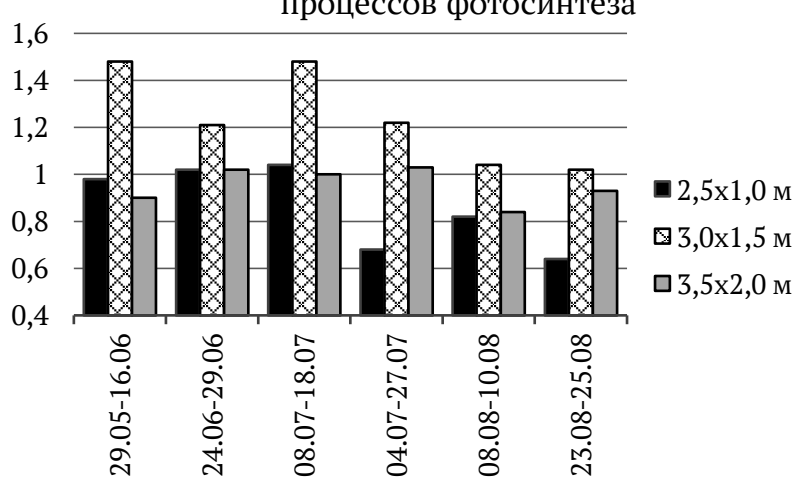

Рис. 2. Физиологические показатели фотосинтетических процессов и формирование продуктивности винограда Рислинг рейнский под влиянием природных и антропогенных факторов, г. Анапа, среднее за 2014-2017 гг.

Fig. 2. Physiological parameters of photosynthetic processes and productivity formation of 'Riesling of the Rhine' grapes under the influence of natural and anthropogenic factors, Anapa, means for 2014-2017

фотосинтезирующих тканях не только в ответ на избыточное освещение, но и на Аругие стрессы, приводящие к снижению активности Цикма Камьвина, такие как засуха и низкие температуры. Соотношение хморофимлы/ каротиноиды показывает устойчивость пигментного аппарата к вторичным стрессам. В среднем за вегетацию во все годы исследований значения этих показателей по вариантам опыта практически не размичались и составляли $2,53-2,55$.

В динамике значения были неодинаковые, в отдельные периоды растения испытывали водный стресс. В насаждениях со среднеплотным размещением кустов наблюдали нарастание этого показателя в течение первой половины вегетации. Пиковые значения соотношения хморофимлы/каротиноиды, характеризующие наличие стрессовой ситуации, были зафиксированы с 8 по 18 июля, в период наибольшей потребности растений винограда во влаге и дефиците атмосферных осадков. Они были наибольшими среди Аругих вариантов опыта и составляли 2,73. В посмеАующем, в августе, наблюдали снижение этого показателя до 2,39. В разреженных насаждениях нарастание соотношения хморофимлы/каротиноиды набцюдалось в течение всего периода вегетации. Наиболее стрессовый период был зафиксирован в конце августа. В период с 10.06 по 16.06 значение бымо равно 2,44, с 16.08 по 25.08 - 2,57. В уплотненных насаждениях наибольшие значения были в начале и конце вегетации, наименьшие - в середине вегетации.

Крахмал явмяется основным продуктом фотосинте- за. В то же время значительное накопмение крахмала в Аистьях может свидетельствовать об ослаблении оттока пластических веществ из Аистьев поА воздействием повышенной температуры и недостатка увлажнения в период вегетации. В динамике во всех вариантах опыта наблюдалось увеличение содержания крахмала до середины июля. Наибольшим содержание крахмала в мистьях винограда было в период с 8.07 по 16.08. Максимальное накопмение крахмаца бымо в уплотненных насаждениях винограда, 8,25-8,47 мг/г сухого вещества, что может быть связано с задержкой фотоассимицятов при повышении температуры. В среднепцотных и разреженных насаждениях содержание крахмала было идентичным и не превышало 6,24 мг/г сухого вещества. В конце августа содержание крахмала снижалось, что свидетельствует о нормальном физиологическом перераспределении пластических веществ в плоды и многолетние органы растения.

\section{Заключение}

Сорт винограда Рислинг рейнский явмяется ценным Аля формирования устойчивых, высокопродуктивных ампемоценозов в изменяющихся нестабильных условиях умеренно континентального кмимата юга России. Сорт хорошо адаптируется и наиболее полно реализует свои биологические и хозяйственно ценные признаки. В результате исследований установлены его агробиологические, физиолого-биохимические и технологические особенности в условиях изменяющегося климата юга России, знание которых кегло в основу формирования сорториентированной технологии. 
$\begin{array}{ll}\text { ВИНОГРАДАРСТВО } & \text { Агхиологические, физиолого-биохимические и } \\ \text { техногичские особенности винограда сорта Рис }\end{array}$

Применение сорториентированной технологии со средней пмотностью размещения кустов 33332222 шт./га по схеме 3,0 x 1,0-1,5 м, обрезкой побегов на 10 глазков, нагрузкой кустов побегами 23 шт./куст и гроздями - 53 шт./куст, будет обеспечивать наибольший уровень реализации фотосинтетического и проАукционного потенциалов винограда. Урожайность в таких насаждениях будет составцять в среднем 12 т/га.

\section{Источники финансирования}

Не указаны

\section{Конфликт интересов}

Не заявлен

\section{Conflict of interests}

Not declared

\section{Список литературы/References}

1. Ампелография СССР, М.: Пищепромиздат, 1955. - Т 5.- С. 134-163,

[Ampelografiya SSSR [Ampelography of the USSR], M.:Pishchepromizdat, 1955. -V5.- pp. 134-163. in Russian)]

2. Daniel Cozzolino, Heather E. Smyth, Wies Cynkar et al. Use of direct headspace-mass spectrometry coupled with chemometrics to predict aroma properties in Australian Riesling wine/ Daniel Cozzolino, Heather E.Smyth, Wies Cynkar, Les Janika Robert G.Dambergs, Mark Gishen// Analytica Chimica Acta, Volume 621, Issue 1, 21 July 2008, pp. 2-7, https://doi.org/10.1016/j.aca.2007.09.036

3. Armin Schüttler, Matthias Friedel, Rainer Jung et al. Characterizing aromatic typicality of Riesling wines: merging volatile compositional and sensory aspects/Armin Schüttler, Matthias Friedel, Rainer Jung, Doris Rauhut, Philippe Darriet// Food Research International, Volume 69, March 2015, Pages 26-37, https://doi.org/10.1016/j.foodres.2014.12.010

4. Amy J. Bowen, Andrew G. Reynolds. Aroma compounds in Ontario Vidal and Riesling ice wines. II. Effects of crop level// Food Research International, Volume 76, Part 3, October 2015, Pages 550-560, https://doi.org/10.1016/j.foodres.2015.06.042

5. Amy J. Bowen, Andrew G. Reynolds, Isabelle Lesschaeve Harvest date and crop level influence sensory and chemical profiles of Ontario Vidal blanc and Riesling icewines /Food Research International, Volume 89, Part 1, November 2016, Pages 591-603, https://doi.org/10.1016/j.foodres.2016.09.005

6. Amy J.Bowen, Andrew G.Reynolds Aroma compounds in Ontario Vidal and Riesling icewines. I. Effects of harvest date// Food Research International, Volume 76, Part 3, October 2015, Pages 540-549, https://doi.org/10.1016/j.foodres.2015.06.046

7. V. Zufferey, F. Murisier, H.R. Schultz A model analysis of the photosynthetic response of Vitis vinifera L. cvs Riesling and Chasselas leaves in the field: I. Interaction of age, light and temperature /VITIS, 39 (2000), pp. 19-26.

8.K. Schoedl, R. Schuhmacher, A. Forneck Correlating physiological parameters with biomarkers for UV-B stress indicators in leaves of grapevine cultivars Pinot noir and Riesling/J. Agric. Sci., 151 (2013), pp. 189-200.

9. C. Lovisolo, I. Perrone, A. Carra, et al. Drought-induced changes in development and function of grapevine (Vitis spp.) organs and in their hydraulic and non-hydraulic interactions at the whole-plant level: a physiological and molecular update. C. Lovisolo, I. Perrone, A. Carra, A. Ferrandino, J. Flexas, H. Medrano, A. Schubert. Funct. Plant Biol., 37 (2010), pp. 98-116

10. B.W. Zoecklein, T.K. Wolf, S.E. Duncan et al. Effect of fruit zone leaf removal on total glycoconjugates and conjugate fraction concentration of Riesling and Chardonnay (Vitis vinifera L.) grapes/ B.W. Zoecklein, T.K. Wolf, S.E. Duncan,
Петров В.С., Анейникова Г.Ю.,

ПавАюкова Т.П., Ненько Н.И., Сундырева М.А.
J.E. Marcy, Y. Jasinski//Am. J. Enol. Vitic., 49(3) (1998), pp. 259-265

11. Reynolds, D A Wardle, A P Naylor, Impact of training system, vine spacing, and basal leaf removal on Riesling, vine performance, berry composition, canopy microclimate, and vineyard labor requirements/American Journal of Enology and Viticulture, 47 (1996), pp. 63-76

12. Michael M. Blanke, Annelene Leyhe, Stomatal Activity of the Grape Berry cv. Riesling, Muller-Thurgau and Ehrenfelser//Journal of Plant Physiology, Volume 127, Issue 5, April 1987, Pages 451-460, https://doi.org/10.1016/ S0176-1617(87)80253-5

13. Josh Mariano Escalona, Sigfredo Fuentes, Magdalena Tomбs et al., Responses of leaf night transpiration to drought stress in Vitis vinifera L./ Josh Mariano Escalona, Sigfredo Fuentes, Magdalena Tomàs, Sebastia Martorell, Jaume Flexas, Hipylito Medrano//Agricultural Water Management, Volume 118, February 2013, Pages 50-58, https://doi.org/10.1016/j. agwat.2012.11.018

14. G.V. Jones, M.A. White, O.R. Cooper, K. Storchmann Climate change and global wine quality// Clim. Change, 73 (2005), pp. 319-343, https://doi.org/10.1007/s10584-0054704-2, интернет ISSN 1573-1480

15. Michelle Renée Mozell, Liz Thach The impact of climate change on the global wine industry: Challenges \& solutions// Wine Economics and Policy, Vol. 3, Issue 2, December 2014, Pages 81-89, https://doi.org/10.1016/j.wep.2014.08.001

16. B. Kozina, M. Karoglan, S. Herjavec et al., Influence of basal leaf removal on the chemical composition of Sauvignon Blanc and Riesling wines / B. Kozina, M. Karoglan, S. Herjavec, A. Jeromel, S. Orlic // Journal of Food, Agriculture and Environment, 6 (1) (2008), pp. 28-33

17. Петров В.С. Потенциал хозяйственной продуктивности винограда, его реализация в условиях умеренно континентального климата юга России // «Магарач». Виноградарство и виноделие, 2016, 1: 20-22.

[Petrov V. S. Potential of economic productivity of grapes, its realization in the conditions of moderate continental climate of the South of Russia. Magarach. Vinogradarstvo i vinodelie = Magarach. Viticulture and winemaking, 2016, 1: 20-22. (in Russian)]

18. Петров В.С., Павлюкова Т.П., Талаш А.И. Научные основы устойчивого выращивания винограда в аномальных погодных условиях. Краснодар: ГНУ СКЗНИИСиВ, 2014.

[Petrov V. S., Pavlyukova T. P., Talash A. I. Scientific bases of steady cultivation of grapes in abnormal weather conditions. Krasnodar: FSBSI NCFSCHVW, 2014. (in Russian)]

19. Павлюкова Т.П., Талаш А.И. Особенности возделывания виноградников в черноморской зоне Краснодарского края: Монография.-Краснодар, 2010 - 140 с. ISBN 978-5-98272-053-5

[Pavlyukova T. P., Talash A. I. Features of cultivation of vineyards in the Black sea zone of Krasnodar region: Monograph.-Krasnodar, 2010 - 140 p. ISBN 978-5-98272053-5. (in Russian)]

20. Петров В.С. Павлюкова Т.П. Закладка эмбриональных соцветий и реализация потенциала хозяйственной продуктивности у сортов винограда в условиях умеренно-континентального климата юга России. Сельскохозяйственная биология, 2018, 3: 616-623, DOI: 10.15389/ agrobiology.2018.3.616rus

[Petrov V. S. Pavlyukova T. P. Laying of embryonic inflorescences and realization of the potential of economic productivity in grape varieties in a temperate continental climate of the South of Russia. Agricultural biology, 2018, 3: 616-623, DOI: 10.15389/agrobiology.2018.3.616 (in Russian)] 
21. Егоров Е.А., Серпуховитина К.А., Петров В.С. и др. Адаптивный потенциал винограда в условиях стрессовых температур зимнего периода // Краснодар: СКЗНИИСиВ, 2006.

[Egorov E. A., Serpukhovitina K. A., V. Petrov Adaptive potential of grapes in stress temperatures conditions in the winter period. Krasnodar:SKZNIISIV [Krasnodar: NCRRIH \& V], 2006. (in Russian)]

22. Егоров Е.А., Петров В.С., Панкин М.И. Потенциал продуктивности винограда: проблемы его реализации на промышленных насаждениях юга России. Виноделие и виноградарство, 2007, 3: 7.

[Egorov E. A., Petrov V. S., Pankin M. I. Productivity potential of grapes: problems of its realization on industrial plantings of the South of Russia. Vinodelie $i$ vinogradarstvo=Winemaking and viticulture, 2007, 3: 7. (in Russian)]

23. Смирнов К.В., Малтабар Л.М., Раджабов А.К., Матузок Н.В. Виноградарство. М., 2017.

[Smirnov K. V., Maltabar L. M., Radzhabov A. K., Matuzok N. V. Viticulture. M., 2017. (in Russian)]

24. Jorger V., Boos M., Ludevig B. Tafeltrauben sind auch fur Baden ein Thema. Bad. Winzer, 2006, 11: 28 - 11.

25. Maigre D. Comportement de quatre clones d'Aligote a Changins. Rev. suisse Vitis. Arboric. Hortic, 2005, Vol. 37, 4: $217-219$.

26. Conner P.J. Performance of Muscadine Grape Cultivars in Southern Georgia // J.Am. Pomol. Soc., 2009, Vol. 63, 3: 101 $-107$.

27. Шевелуха В.С. Рост растений и его регуляция в онтогенезе. М.: Колос, 1997.

[Shevelukha, V. S. Plant growth and its regulation in ontogenesis. M.: Kolos, 1997. (in Russian)]

28. Рубин А.Б., Венедиктов П.С., Кренделева Т.Е. и др. Регуляция первичных стадий фотосинтеза при изменении физиологического состояния растений // Фотосинтез и продукционный процесс. М., 1988: 29 - 39.

[Rubin A. B., Venediktov P. S., Krendeleva T,E, etc. Regulation of primary stages of photosynthesis at change of physiological condition of plants. Photosynthesis and production process. M., 1988: 29 - 39. (in Russian)]

29. Методическое и аналитическое обеспечение организации и проведения исследований по технологии производства винограда/Под ред. К.А. Серпуховитиной. Краснодар, 2010.

[Methodological and analytical support to organization and research on technology of grape production, Ed. K. A. Serpukhovitina. Krasnodar, 2010. (in Russian)]

30. I. Pearce, B.G. Coombe Grapevine phenology, Viticulture. Resources, vol. 1, Winetitles, Adelaide (2004), pp. 150-166

31. Hans R. Schultz An empirical model for the simulation of leaf appearance and leaf area development of primary shoots of several grapevine (Vitis vinifera L.) canopy-systems, Scientia Horticulturae, Volume 52, Issue 3, November 1992, Pages 179-200 https://doi.org/10.1016/0304-4238(92)90020-D

32. Antonio F. Nogueira Jünior, Lilian Amorim, Serge Savary et al. Modelling the dynamics of grapevine growth over years/ Antonio F. Nogueira Júnior, Lilian Amorim, Serge Savary, Laetitia Willocquet//Ecological Modelling, Volume 369, 10 February 2018, Pages 77-87, https://doi.org/10.1016/j. ecolmodel.2017.12.016

33. Kare P. Mahmud, Bruno P. Holzapfel, Yann Guisard et al., Circadian regulation of grapevine root and shoot growth and their modulation by photoperiod and temperature/ Kare P.Mahmud, Bruno P.Holzapfel, Yann Guisard, Jason P. Smith, Sharon Nielsen, Suzy Y.Rogiers. Journal of Plant Physiology, Volume 222, March 2018, Pages 86-93, https:// doi.org/10.1016/j.jplph.2018.01.006

ORCID ID:

Петров В.С. https://orcid.org/0000-0003-0856-7450

Алейникова Г.Ю. https://orcid.org/0000-0002-9959-2522

Павлюкова Т.П. https://orcid.org/0000-0003-3687-3922

Ненько Н.И. https://orcid.org/0000-0001-9494-7868

Сундырева М.A. https://orcid.org/0000-0002-1338-1725 